\title{
REGULASI DAN PENGAWASAN FINTECH DI INDONESIA: PERSFEKTIF HUKUM EKONOMI SYARIAH
}

\author{
Oleh: Muhammad Fachrurrazy ${ }^{1}$; Dirah Nurmila Siliwadi ${ }^{2}$ \\ ${ }^{1}$ Hukum Ekonomi Syariah, Fakultas Syariah, IAIN Palopo, Indonesia \\ ${ }^{2}$ Hukum Tata Negara, Fakultas Syariah, IAIN Palopo, Indonesia \\ Email: ${ }^{1}$ muh_fachrurrazy@iainpalopo.ac.id \\ 2dirahsiliwadi@iainpalopo.ac.id
}

Article history:

Received: $29-08-2020$

Revised: 01-09-2020

Accepted: 02-09-2020

\begin{abstract}
Technology-based financial innovation has an important role to develop national economic, regulatory and surveillance controls haven't completely protected against legal and illegal fintech breaches. This study aims to analyze government policies in monitoring and providing legal protection against conflict in fintech and sharia violations. Research show fintech arrangements and surveillance are currently on financial service authority (POJK) and Indonesian's central bank regulations (PBI) as the main regulator, and then the Fatwa DSNMUI and the council governors rule (PADG BI) as the fan regulator. Fintech surveillance regulations are currently not running optimal because current surveillance was applied to a pre-operational stage due to regulations and oversight barriers.
\end{abstract}

Keywords: Fintech; Islamic Economic Law; Legal Protection; Surveillance.

\begin{abstract}
Abstrak
Inovasi keuangan berbasis teknologi (fintech) memiliki peranan penting dalam perkembangan ekonomi nasional, kontrol regulasi dan pengawasan belum sepenuhnya melindungi dari pelanggaran-pelanggaran fintech legal maupun ilegal. Penelitian ini bertujuan untuk menganalisis kebijakan pemerintah dalam mengawasi dan memberikan perlindungan hukum terhadap pelanggaran fintech konvensional dan syariah. Hasil penelitian menunjukkan pengaturan dan pengawasan fintech saat ini diatur dalam Peraturan Otoritas Jasa Keuangan (POJK) dan Peraturan Bank Indonesia (PBI) sebagai regulator utama. Kemudian Fatwa DSN-MUI dan Peraturan Dewan Anggota Gubernur BI serta konteks fiqh muamalah sebagai regulator pendukung. Pelaksanaan regulasi pengawasan fintech saat ini belum dapat berjalan optimal karena pengawasan baru dilaksanakan pada tahap pra operasional usaha disebabkan hambatan regulasi dan infrastruktur pengawasan.
\end{abstract}

\section{Kata Kunci : Fintech, Hukum Ekonomi Syariah; Perlindungan Hukum; Pengawasan.}




\section{A. Pendahuluan}

Perkembangan teknologi di era milenial ini adalah suatu kebutuhan, dimana layanan terhadap masyarakat semakin canggih, cepat, dan mumpuni. Salah satu perkembangan teknologi di era milenial ini, adalah bidang layanan keuangan, dengan inovasinya menggandeng kecanggihan teknologi sebagai sarana penyaluran traksaksi keuangan di tengah masyarakat. Istilah inovasi tersebut, dinamakan teknologi finansial atau "financial technologi" (fintech).

Defenisi fintech menurut Bank Indonesia, adalah penggunaan teknologi dalam sistem keuangan yang dapat menghasilkan produk, layanan, teknologi, dan/atau model bisnis baru dengan beberapa kategori sebagai sistem pembayaran, pendukung pasar, manajemen investasi dan manajemen resiko, pinjaman, pembiayaan dan penyediaan modal serta jasa finansial lainnya, dengan kriteria inovatif, bermanfaat bagi masyarakat, dapat digunakan secara luas, dan kriteria lain yang ditetapkan oleh Bank Indonesia. ${ }^{1}$

Seiring dengan perkembangan industri "fintech" tersebut, ditandai dengan mobilitas masyarakat di era milenial ini, teknologi sudah menjadi kebutuhan yang pokok dan keterbukaan akses informasi dari berbagai sektor, ekonomi, hukum, politik, sosial, dan lain lain.

Untuk mendorong perkembangan ekonomi nasional, salah satu cara misalnya, dengan penerapan Peraturan Presiden Nomor 82 Tahun 2016 tentang Strategi Nasional Keuangan Inklusif, yang memberikan keterbukaan akses bagi masyarakat, untuk mengakses layanan keuangan formal yang berkualitas, tepat waktu, lancar, dan aman dengan biaya terjangkau sesuai dengan kebutuhan dan kemampuan masing-masing.

Kelompok masyarakat yang diprioritaskan untuk mendapat akses keuangan antara lain masyarakat berpenghasilan rendah (dalam hal ini MBR atau keluarga prasejahtera), pelaku UMKM, pekerja migran, wanita, disabilitas, anak terlantar, lansia, penduduk daerah tertinggal, serta pelajar dan pemuda. ${ }^{2}$

${ }^{1}$ https://www.bi.go.id/id/sistem-pembayaran/fintech/Content : diakses pada 1 agustus pkl

2 https://id.m.wikipedia.org/wiki/Inklusi_keuangan. 
Saat ini, kebijakan-kebijakan terkait regulasi mengenai fintech tersebut telah ada, beberapa di antara peraturan yang sesuai dengan fungsi layanan keuangan fintech ke masyarakat baik secara konvesional maupun beradasarkan prinsip syariah. Peraturan-Peraturan fintech tersebut adalah berdasarkan otoritas lembaga pemerintah yang menaungi layanan fintech itu sendiri. berdasarkan fungsi fintech tersebut ada 4 jenis fintech yang beroperasi di Indonesia yaitu: ${ }^{3}$

Pertama, payment, clearing dan settlement. Ini adalah fintech yang memberikan layanan sistem pembayaran, baik yang diselenggarakan oleh industri perbankan maupun yang dilakukan Bank Indonesia. Seperti Bank Indonesia Real Time Gross Settlement (BI-RTGS), Sistem Kliring Nasional BI (SKNBI) hingga BI scripless Securities Settlement System (BI-SSSS). Contohnya, Kartuku, Doku, iPaymu, Dana, Ovo;

Kedua, e-aggregator. Fintech ini menggumpulkan dan mengolah data yang bisa dimanfaatkan konsumen untuk membantu pengambilan keputusan. Startup ini memberikan perbandingan produk mulai dari harga, fitur hingga manfaat. Contohnya, Cekaja, Cermati, KreditGogo dan Tunaiku;

Ketiga, manajemen resiko dan investasi. Fintech ini memberikan layanan seperti robot advisor (perangkat lunak yang memberikan layanan perencanaan keuangan dan platform e-trading dan e-insurance). Contohnya, Ajaib, Dana Syariah, Bareksadana;

Keempat, peer to peer Lending (P2P). Fintech ini mempertemukan antara pemberi pinjaman (investor) dengan para pencari pinjaman dalam satu platform. Nantinya para investor akan mendapatkan bunga atau bagi hasil dari dana yang dipinjamkan. Contohnya, Modalku, Investree, Amartha dan Syarfi.

Dari keempat jenis fintech yang beroperasi di sektor keuangan untuk memenuhi kebutuhan masyarakat dalam layanan keuangan. Namun, hal tersebut tentu pula beriringan dengan tantangan dan resiko yang akan dihadapi, baik dari sisi masyarakat sebagai pengguna layanan, perusahaan sebagai penyedia jasa

${ }^{3}$ Roy Franedya, Tito Bosnia; "Ini dia empat jenis fintech di Indonesia"; Https://Www.Cnbcindonesia.Com/Tech/20180110145800-37-1126/Ini-Dia-Empat-Jenis-Fintech-di - Indonesia, diakses pada 14 juli 2020 
layanan fintech, serta pemerintah yang memegang otoritas dimana regulasi dan pengawasan berupa peraturan untuk mengatur serta melindungi para pihak terkait layanan fintech tersebut.

Saat ini banyak kasus yang terjadi akibat layanan fintech, mulai dari pembobolan data konsumen secara sepihak, penentuan suku bunga yang selangit, proses penagihan secara intimidatif dan pelecehan seksual bahkan sampai berujung maut. Dari sumber berita ditemukan seorang supir taksi berinisial $\mathrm{Z}$ (35th) Bunuh diri karena terjerat aplikasi pinjaman online dan tidak mampu membayar. 4

Kemudian sampai pertengahan 2019, data dari Lembaga Bantuan Hukum (LBH) di Jakarta, mencapai 4500 aduan mengenai fintech Lending, selain itu pula satgas waspada investasi melaporkan ada sebanyak 683 entitas fintech peer to peer (P2P) Lending ilegal, mulai dari 2018 hingga 2019, sagtas waspada investasi menghentikan 1.087 entittas fintech ilegal. ${ }^{5}$

Menyikapi persoalan di atas pemerintah melakukan upaya untuk membuat aturan mengenai fintech tersebut, kendatipun belum sepenuhnya melindungi masyarakat, namun upaya tersebut perlu ditingkatkan terutama aspek hukum yang mengadili tindak pelanggaran fintech. Sejak dilegalisasi secara nasional layanan keuangan berdasarkan prinsip syariah, dimulai dari pertumbuhan Bank dan lembaga keuangan lainnya, berdasarkan prinsip syariah mendorong upaya regulasi hukum Islam terkait perkembangan layanan keuangan fintech tersebut.

Terbitnya fatwa No:117/DSN-MUI/II/2018 Tentang Layanan Pembiayaan Berbasis Teknologi Informasi Berdasarkan Prinsip Syariah, adalah produk hukum yang sesuai penerapan hukum Islam dalam mengawal perkembangan fintech tersebut, tentu pula untuk mendukung supremasi hukum yang berlaku. Hal ini menunjukkan bahwa hukum Islam, khusus dalam bidang muamalah memiliki

${ }^{4}$ Jimmy Ramadhan Azhari : " Terjerat utang online, supir taksi tulis surat sebelum gantung diri”; https://megapolitan.kompas.com/read/2019/02/11/14544111/terjerat-utang-online-sopirtaksi-tulis-surat-sebelum-gantung-diri., diakses pada 10 juli 2020.

${ }^{5}$ Agustinus Respati; "Banyak Kasus, tingkat kepercayaan terhadap fintech menciut"; https://www.google.com/amp/amp.kontan.co.id/news/banyak-kasus-tingkat-kepercayaan-terhadapfintech-menciut., diakses pada 14 agustus 2020 . 
peran penting untuk menjawab persoalan fintech, khususnya memyangkut fintech berdasarkan prinsip syariah dalam kegiatan operasionalnya.

Meski dalam ketetapan ketujuh, tentang peyelesaian perselisihan Fatwa No:117/DSN-MUI/II/2018 menyebutkan; ${ }^{6}$ "Penyelesaian sengketa di antara para pihak dapat dilakukan melalui musyawarah mufakat. Apabila musyawarah mufakat tidak tercapai, maka penyelesaian sengketa dilakukan melalui lembaga penyelesaian sengketa berdasarkan syariah sesuai peraturan perundang-undangan yang berlaku". Atas dasar itulah penulis ingin mengkaji lebih dalam mengenai regulasi dan pengawasan fintech di Indonesia tertutama dari sisi perpektif hukum ekonomi syariah. Sejauh ini beberapa penelitian terkait regulasi dan pengawasan yang mengkaji fintech diantaranya:

Pertama; Artikel dengan judul "Analisa Regulasi Fintech dalam Membangun Perekonomian di Indonesia" Oleh Budi Wibowo yang menguraikan kerangka regulasi fintech untuk membangun perekonomian Indonesia. fokus kajian perlukah regulasi untuk mengantur fintech dan dalam hasil kajian nya menemukan ada ruang ratifikasi peraturan yang mendukung fintech di Indonesia, serta adanya koordinasi dari kementerian terkait, sebagai upaya dari pemerintah membangun layanan keuangan berbasis teknologi ${ }^{7}$

Kedua, Artikel dengan judul "Fintech, Regulatory Arbitrage, And The Rise Of Shadow Banks" Oleh Greg Buchak, Gregor Matvos, Tomasz Piskorski, Amit Seru, dalam jurnal National Bureau Of Economic Research. ${ }^{8}$ Dalam artikel tersebut mengurai menjelaskan dan menganalisa dampak peraturan setelah krisis di tiga sektor sekaligus yakni Bank, Pembiayaan (Shadow Bank), dan fintech. Dimana regulasi terhadap ketiga lembaga keuangan tersebut memberi keuntungan yang lebih kepada sektor pembiayaaan (shadow Bank) tersebut. Hal tersebut menimbulkan kegelisahan, dimana peraturan perlu dibuat untuk mengawasi

\footnotetext{
${ }^{6}$ Fatwa Dewan Syariah Nasional-Majelis Ulama Indonesia No:117/DSN-MUI/II/2018 Tentang Layanan Pembiayaan Berbasis Teknologi Informasi Berdasarkan Prinsip Syariah.

7Budi Wibowo,“Analisa Regulasi Fintech Dalam Membangun Perekonomian di Indonesia”, https://www.academia.edu/35563302/analisa_regulasi_fintech_dalam_membangun_perekonomian __di_Indonesia.

${ }^{8}$ Greg Buchak, et al, "Fintech, Regulatory Arbitrage, And The Rise Of Shadow Banks", National Bureau of Economic Research, No.23288, Sepetember 2018.
} 
perkembangan pembiayaan (Shadow Bank) lebih ketat seperti hal Bank dan Fintech;

Ketiga, Artikel dengan judul "Pengawasan Otoritas Jasa Keuangan Terhadap Financial Technology (Peraturan Otoritas Jasa Keuangan Nomor 77/Pojk.01/2016)" Oleh Ernama Santi , Budiharto Budiharto, Hendro Saptono Fakultas Hukum, Universitas Diponegoro, Indonesia. Dalam artikel tersebut fokus mengkaji pengawasan fintech terkait Peraturan Otoritas jasa keuangan No.77/POJK.01/2016 layanan pinjam meminjam uang berbasis teknologi informasi, dengan Hasil kajian pengawasan peraturan terkait mekanisme menjalan perusahaan berbasis fintech mulai dari pra-operasional dan saat operasional usaha itu berjalan serta pelaksaan pengawasan sesuai dengan ketetuan peraturan terkait; ${ }^{9}$

Keempat, Artikel dengan judul "Peluang dan Tantangan Fintech (Financial Technology) Syariah di Indonesia" Oleh Hida Hiyanti, Lucky Nugroho, Citra Sukmadilaga, Tettet Fijriyanti, yang menjelaskan prospek fintech syariah sebagai solusi perekonomian nasional serta tantangan yang dihadapi dalam perkembangannya. Hasil kajian ini meliputi pembagian dari sisi kekuatan dan kelemahan fintech syariah dihadapkan pada fintech konvesional dan regulasi pemerintah yang mengantur aspek fintech syariah; ${ }^{10}$

Kelima, Artikel dengan judul "Islamic Financial Technology (Fintech): Its Challenges And Prospect"11 oleh Egi Arvian Firmansyah, Mohammad Anwar, yang meneliti tentang tantangan aspek regulasi fintech syariah di dunia, lalu dibandingkan dengan fintech syariah di Indonesia, sejauh ini tantangan terbesar dalam hasil pembahasan fintech syariah adalah regulasi yang diterapkan jika terlalu longgar atau terlalu ketat, di Indonesia sendiri telah membentuk badan asosiasi fintech sebagai kontrol regulasi perkembangan fintech.

\footnotetext{
${ }^{9}$ Ernama Santi, et al, 'Pengawasan Otoritas Jasa Keuangan Terhadap Financial Technology (Peraturan Otoritas Jasa Keuangan Nomor 77/Pojk.01/2016)”, Diponegoro Law Journal, Vol.6 No.3, Juli 2017.

${ }^{10}$ Hida Hiyanti, et al, "Peluang dan Tantangan Fintech (Financial Technology) Syariah di Indonesia”, Jurnal Ilmiah Ekonomi Islam (JIEI), Vol.5 No.3, 2019.

${ }^{11}$ Egi Alvian Firmansyah, et al, "Islamic Financial Technology (Fintech): Its Challenges And Prospect", Proceedings of the Achieving and Sustaining SDGs 2018 Conference: Harnessing the Power of Frontier Technology to Achieve the Sustainable Development Goals (ASSDG 2018) Atlantis Press, January 2019.
} 
Adapun tujuan penelitian ini, adalah menganalisis kebijakan pemerintah dalam mengawasi dan memberi perlindungan hukum terhadap pelanggaran fintech, kemudian menganalisis pandangan hukum ekonomi syariah tentang aturan-aturan fintech yang ada di Indonesia.

Dari sudut pandang tersebut penulis beranggapan, dari semua peraturan yang telah disusun oleh pemerintah, perlu adanya suatu kaidah hukum sebagai delegasi hukum yang mengatur khusus mengenai fintech. Mengingat banyaknya laporan mengenai pelanggaran fintech, baik yang legal maupun ilegal menunjukkan bahwa pengawasan dan pengaturan mengenai layanan keuangan ini belum sepenuhnya dapat menjerat para pelaku pelanggaran fintech.

Jika dilihat dari klausula tetapan DSN-MUI, dalam mengantisipasi dan mengawasi jika terjadi tindak pelaggaran fintech, akan tetapi untuk mengidentifikasi berbagai bentuk pelanggaran fintech belum maksimal jika mengandalkan klausula tetapan tersebut. Sehingga mungkin perlu adanya sinergi antara peraturan-peraturan yang khusus mengesampingkan ketentuan yang bersifat umum (asas lex specialis degorat legi generalis). ${ }^{12}$

\section{B. Pembahasan}

Regulasi dan pengaturan mengenai pengawasan OJK terhadap fintech dalam hal ini layanan pinjam meminjam uang berbasis Teknologi Informasi (P2P Lending) diatur di dalam POJK Nomor 77/POJK.01/2016. Pengawasan terhadap fintech P2P Lending atau pinjam meminjam uang online dibagi menjadi dua tahapan: pra atau sebelum operasional usaha dilakukan, dan pada saat atau berlangsungnya operasional usaha. Tahapan pra operasional usaha, dalam tahap pra atau sebelum operasional usaha berjalan wajib melakukan pendaftaran dan izin penyelenggara oleh pihak penyelenggara dalam hal ini OJK, baik itu badan hukum yang berbentuk perseroan terbatas ataupun koperasi sebagaimana yang termuat dalam pasal 7 POJK Nomor 77/POJK/01/2016.

Untuk mendapatkan surat tanda bukti terdaftar dari OJK. Terlebih dahulu direksi mengajukan pendaftaran yang paling lambat diajukan 6 (enam) bulan kepada Kepala Eksekutif Pengawsan Perasuransian, Lembaga Pembiayaan, Dana

${ }^{12}$ Bagir Manan, "Hukum positif Indonesia : Suatu kajian teoritik", FH UII Press, Yogyakarta 
Pensiun, dan Lembaga Jasa Keuangan Lainnya, menggunakan formulir beserta lampiran dokumen yang tertera dalam pasal 8 ayat (3) POJK Nomor 77/POJK/01/2016.

Kemudian OJK akan menelaah permohonan pendaftaran dari penyelenggara layanan keuangan berbasis teknologi informasi dan akan mendapat persetujuan atas permohonan tersebut dalam jangka waktu 10 (sepuluh) hari kerja. Penyelenggara yang berbentuk badan perseroan terbatas (PT) dapat dimiliki dan didirikan oleh warga negara asing, warga negara Indonesia, badan hukum asing atau badan hukum Indonesia. Secara khusus bagi penyelenggara warga negara asing atau badan hukum asing, kepemilikan saham baik itu secara langsung maupun tidak langsung paling banyak mencapai $85 \%$.

Setiap penyelenggara yang telah terdaftar di OJK wajib untuk mengajukan permohonan izin sebagai penyelenggara dalam jangka waktu paling lama 1 (satu) tahun sejak tanggal terdaftar di OJK. Apabila dalam jangka waktu selama 1 (satu) tahun yang diberikan oleh OJK tersebut, penyelenggara yang telah mendapat surat tanda bukti terdaftar dan tidak menyampaikan permohonan perizinan, maka surat tanda bukti terdaftar sebagai penyelenggara menjadi batal dan penyelenggara tersebut tidak lagi terdaftar di OJK, dan tidak dapat lagi mengajukan permohonan pendaftaran kembali kepada OJK.

Pasal 11 POJK Nomor 77/POJK.01/2016, mengatur tentang syarat-syarat pengajuan permohonan perizinan. Dalam jangka waktu paling lama 20 (dua puluh) hari kerja sejak diterimanya dokumen permohonan perizinan, OJK akan memberikan persetujuan atau penolakan atas permohonan perizininan. Selama 20 (dua puluh) hari tersebut, OJK melakukan penelitian atas kelengkapan dokumen dan analisis kelayakan atas rencana kerja. Dalam proses memberikan izin tersebut, dimungkinkan OJK untuk melakukan wawancara terhadap pemilik dan/atau calon direksi dan verifikasi langsung ke kantor pemohon izin. Pelaksanaan wawancara tersebut sebagai sarana fit and proper test terhadap calon direksi/komisaris penyelenggara.

Wawancara di atas juga untuk memeriksa bahwa setoran modal tidak berasal dari pinjaman atau kegiatan pencucian uang (money laundering) dan kejahatan keuangan lainnya, tidak tercatat dalam daftar kredit macet, tidak pernah 
dihukum karena melakukan tindak pidana dibidang usaha jasa keuangan dan/atau perekonomian berdasarkan putusan pengadilan yang telah mempunyai kekuatan hukum tetap dalam 5 (lima) tahun terakhir dan tidak pernah dinyatakan pailit berdasarkan putusan pengadilan yang mempunyai kekuatan hukum tetap.

Di dalam pengawasan tahap pra-operasional ini, diatur mengenai pengawasan OJK terhadap perubahan kepemilikan penyelenggara yang harus terlebih dahulu mendapatkan persetujuan dari OJK. Selain itu, apabila penyelenggara yang telah memperoleh izin dan menyatakan tidak mampu meneruskan kegiatan operasionalnya, harus mengajukan permohonan perncabutan izin atas permohonan sendiri kepada OJK, dengan disertai alasan ketidakmampuan, dan rencana penyelesaian hak dan kewajiban penggunaan. Pencabutan izin tersebut paling lambat 20 (duapuluh) hari kerja sejak tanggal permohonan pencabutan.

Saat operasional usaha kegiatan penyelenggaraan layanan pinjam meminjam uang berbasis teknologi informasi, baru dapat dimulai ketika telah mendapat izin dari OJK. Terdapat dua macam tipe pengawasan yang dilakukan oleh OJK saat operasional usaha, yaitu pengajuan laporan oleh perusahaan atau penyelenggara (self assessment system) dan pemeriksaan oleh OJK (officer supervitsory system). Kegiatan penyelenggaraan atau saat operasional sudah akan berjalan ketika telah mendapat izin dari OJK, untuk melaksanakan layanan pinjam meminjam uang berbasis teknologi informasi.

Tipe pengawasan yang pertama ditempuh oleh OJK pada saat operasional usaha, seperti pengajuan laporan oleh perusahaan atau penyelenggara (self assessment system), pengawasan berupa pengawasan terhadap keuangan dan kegiatan usaha serta pengawasan terhadap pelaksanaan anggaran dasar yang dilaksanakan melalui laporan berkala ini diatur dalam POJK Nomor 77/POJK.01/2016, biasanya dalam tahap operasional ini, ada penyelenggara yang belum mengajukan izin penyelenggaraan kepada OJK. namun sudah memulai kegiatan usahanya. OJK tetap akan melakukan pengawasan dengan laporan berkala atau biasa disebut tipe pengawasan Self assessment system.

Tipe laporan ini menyampaikan pelaksanaan kegiatan usaha yang dilakukan setiap 3 (tiga) bulan, yang berakhir masa periodenya pada tanggal 31 
Maret, 30 Juni, dan 30 September, serta pada batas pengajuan izin penyelenggaraan berakhir.

Dalam pasal 45 hingga Pasal 56 POJK Nomor77/POJK.01/2016 menyebutkan ${ }^{13}$ bahwa terkhusus penyelenggara yang telah memperoleh izin wajib untuk memberikan laporan berkala secara elektronik yaitu laporan bulanan dan laporan tahunan kepada OJK. Bagi laporan bulanan disampaikan selambatlambatnya 10 (sepuluh) hari kerja pada bulan berikutnya, sedangkan untuk laporan tahunan periode pelaporan 1 Januari hingga 31 Desember agar disampaikan kepada OJK, yang berbentuk fisik maupun dokumen elektronik. Laporan tahunan terdiri dari laporan kegiatan penyelenggaraan layanan pinjam meminjam uang berbasis teknologi dan laporan keuangan, jangka waktu penyampaian laporan tersebut selambat-lambatnya 20 (dua puluh) hari kerja setelah periode pelaporan berakhir. ${ }^{14}$

Tipe pengawasan yang kedua adalah officer supervisory system, yakni pemeriksaan berkala yang dilakukan oleh OJK. Pemeriksaan merupakan rangkaian kegiatan yang dilakukan oleh OJK untuk mengumpulkan, mencari, mengolah, mengevaluasi data dan informasi mengenai kegiatan usaha layanan pinjam meminjam uang berbasis teknologi informasi, paling lambat 10 (sepuluh) hari kerja terhitung sejak jatuh tempo tanggal pelaporan.

Laporan berkala ini berjangka waktu 1 (satu) tahun, dan akan melakukan pengawasan secara berkala yang bertujuan untuk memastikan bahwa laporan berkala yang disampaikan oleh penyelenggara sesuai dengan keadaan perusahaan yang sebenarnya. Selain pengawasan laporan berkala, OJK juga melakukan pemeriksaan untuk memperoleh keyakinan atas kebenaran laporan berkala serta menilai kepatuhan terhadap ketentuan yang berlaku. Pemeriksaan OJK dilakukan setiap satu bulan sekali, untuk memeriksa laporan bulanan yang disampaikan oleh penyelenggara. Bertujuan untuk melihat kebenaran aspek susbtansi laporan

13Pasal 56 Peraturan Otoritas Jasa Keuangan Nomor77/POJK.01/2016.

${ }^{14}$ Mireza Fitriadi "et al", "Kedudukan Otoritas Jasa Keuangan Terhadap Perusahaan Modal Ventura Asing dalam Melakukan Pembiayaan Secara Langsung di Indonesia", Jurnal Penelitian Hukum, Vol. 1, Nomor 2, Juli 2014, h..81. 
berkala dan kepatuhan terhadap ketentuan perundang-undangan, dan jika diperlukan OJK dapat meminta informasi tambahan dan/atau data tambahan kepada penyelenggara. Sama halnya dengan pemeriksaan terhadap laporan tahunan, dimana OJK dapat meminta informasi tambahan dan/atau data tambahan kepada penyelenggara.

Selain pemeriksaan berkala, OJK juga dimungkinkan untuk melakukan pemeriksaan incidental, jika berdasarkan hasil analisis atas laporan bulanan tersebut patut diduga menyimpang dari ketentuan yang berlaku. Selain itu pemeriksaan insidental dapat dilakukan apabila berdasarkan hasil penelitian, atas keterangan yang didapat OJK dari surat pengaduan, patut diduga bahwa penyelenggara kegiatan usaha menyimpang, salah satunya tidak memenuhi hak nasabah.

Pelaksanaan pemeriksaan insidental ini, juga dapat berupa pemeriksaan terhadap rekam jejak audit guna keperluan pengawasan, penyelesaian sengketa, verifikasi, pengujian dan pemeriksaan lainnya. Bentuk pengawasan lain yang dilakukan oleh OJK adalah pengawasan terhadap pelaksanaan kegiatan usaha dengan mengatur beberapa ketentuan larangan di dalam Pasal 43 POJK Nomor 77/POJK.01/2016. ${ }^{15}$

Pada akhir tahun 2016, OJK telah mengeluarkan POJK Nomor 77/POJK.01/2016 tentang Layanan Pinjam Meminjam Uang Berbasis Teknologi Informasi. Peraturan ini menjadi dasar pelaksanaan kegiatan usaha P2P Lending atau pinjam meminjam online, yang merupakan salah satu jenis fintech, termasuk di dalamnya pengaturan mengenai pengawasan yang dilakukan oleh OJK terhadap berjalannya penyelenggaraan kegiatan usaha tersebut. Penyelenggaraan fintech P2P Lending dalam POJK di atas dikelompokkan sebagai lembaga jasa keuangan lain, yang masuk dalam ranah pengawasan sektor industri keuangan non Bank.

Sebagai lembaga jasa keuangannya lainnya, tentu pelaksanaan fintech $\mathrm{P} 2 \mathrm{P}$ Lending haruslah diawasi oleh OJK sebagai otoritas yang memiliki kewenangan untuk melakukan pengawasan terhadap mikroprudensial di Indonesia. Perbedaan secara umum pengawasan terhadap fintech yang dilakukan oleh Bank Indonesia

15Pasal 43 Peraturan Otoritas Jasa Keuangan Nomor77/POJK.01/2016. 
dan OJK, yakni BI menangani fintech yang masuk ke dalam kategori sistem pembayaran, termasuk di dalamnya perusahaan-perusahaan yang menyediakan jasa payment gateway, remittance, e-wallet, switching, dan lainnya.

Sedangkan OJK menangani fintech, di antaranya yang bergerak di bidang $\mathrm{P} 2 \mathrm{P}$ Lending/financing, insurance, dan sebagainya. Jenis kegiatan usaha pendukung atau enabler fintech contohnya e-KYC, robo advisor, big data, dan lainnya akan ditangani lintas otoritas. Hasil pelaksanaan pengawasan oleh OJK saat ini, Muhammad Mufid, Kepala Bagian Pengawasan Lembaga Pembiayaan 3 OJK, menyatakan bahwa saat ini pengawasan yang dilakukan oleh OJK, terhadap kegiatan penyelenggaraan fintech $\mathrm{P} 2 \mathrm{P}$ Lending atau pinjam meminjam online saat ini hanya pada tahap pra- operasional usaha.

Fokus utama OJK pasca diundangkannya POJK Nomor 77/POJK.01/2016, adalah pengajuan pendaftaran dan perizinan bagi perusahaan yang bergerak dalam bidang layanan pinjam meminjam uang atau P2P Lending, sebagai bagian dari pengawasan tahap pra- operasional usaha. Alasan lain yang melatarbelakangi belum berjalannya pengawasan secara penuh adalah belum adanya departemen di bawah OJK yang secara khusus menangani fintech sebagaimana BI Fintech Office di bawah Bank Indonesia. Saat ini OJK sedang mendesain struktur organisasi dalam rangka pengembangan dan pengawasan fintech.

Hal ini dimaksudkan untuk menemukan formulasi yang tepat, terkait dengan pelaksanaan pengaturan serta pengawasan terhadap fintech di Indonesia agar selaras dengan tujuan pembangunan yang ingin dicapai dalam bidang ekonomi. Terkait dengan hal ini, Asosiasi Fintech Indonesia (AFTECH) terus mendorong pembentukan departemen fintech di OJK, agar dapat menyelesaikan persoalan- persoalan fintech, khususnya $\mathrm{P} 2 \mathrm{P}$ Lending, sebagai tindak lanjut dan komitmen regulator pasca diterbitkannya POJK 77/POJK.01/2016.

Menurut Muhammad Mufid, terkait dengan pengawasan saat ini lebih kepada pengembangan dari perusahan fintech. Pengembangan merupakan fungsi yang melekat pada pengawasan. Sebagai contoh adalah terkait dengan saran dan masukan dari setiap produk jasa keuangan yang ditawarkan. Adanya komunikasi 
yang dilakukan oleh para pelaku perusahaan fintech yang kemudian dilakukan pendataan oleh OJK dapat diartikan sebagai bentuk pengawasan secara luas. ${ }^{16}$

Pengawasan pra-operasional tersebut, baru dapat dimulai ketika perusahaan melakukan pendaftaran. Terkait dengan pelaksanaan pengawasan pada tahap pra- operasional tersebut, berdasarkan POJK 77/2016, setiap penyelenggara P2P Lending atau pinjam meminjam online wajib mengajukan pendaftaran dan perizinan kepada OJK. Per Maret 2017, data terakhir oleh Asosiasi Fintech Indonesia terdapat sekitar 30 perusahaan yang telah mengajukan permohonan pendaftaran ke OJK dan sedang diproses secara internal oleh OJK.

Di antara jumlah tersebut baru 1 perusahaan yang dinyatakan terdaftar/lolos pendaftaran. Perusahaan tersebut adalah Pinjam Indonesia (pinjam.co.id). Perusahaan yang telah terdaftar di OJK. Kemudian wajib untuk menyampaikan laporan berkala seperti yang diatur di dalam POJK Nomor 77/POJK.01/2016. Dalam masa pendaftaran ini, Penyelenggara telah dapat melakukan aktivitas secara penuh dengan mendapat pendampingan dari OJK yang secara terus menerus melakukan evaluasi. Paling lama 1 (satu) tahun setelah terdaftar, Penyelenggara wajib mengajukan permohonan untuk memperoleh izin kepada OJK.

Menurut M. Ajisatria Suleiman, Direktur Kebijakan Publik AFTECH, setelah perusahaan fintech terdaftar, maka OJK akan memberikan pengawasan dan pembinaan sampai dengan maksimal 1 tahun untuk mendapatkan izin dari OJK. Dalam hal ini, baik dalam aspek permodalan maupun pada operasional bisnis $\mathrm{P} 2 \mathrm{P}$ Lending, diharapkan telah mapan setelah melalui proses tersebut dan dapat diberikan izin oleh OJK. ${ }^{17}$

Namun, secara umum, dari fintech yang telah terdaftar sesuai POJK $77 / 2016$, OJK terbuka terhadap masukan para pelaku usaha dalam hal pembuatan regulasi maupun tindak-lanjutnya. Dalam rangka mendorong upaya pengawasan yang dilakukan oleh OJK, AFTECH sedang menyusun Code of Conduct bersama para pelaku P2P Lending. Poin-poin yang sedang dibahas, di antaranya sharing

${ }^{16}$ Muhammad Mufid, 2016. Wawancara "Pelaksanaan Pengawasan OJK terhadap Financial Technology" di OJK. Jakarta, 12 April 2016.

${ }^{17}$ M. Ajisatria Suleiman, 2016. Wawancara "Pelaksanaan Pengawasan OJK terhadap Financial Technology” di Asosiasi Financial Technology Indonesia. Jakarta, 11 April 2017. 
negative list, tidak diperbolehkan poaching SDM antar platform, dan penggunaan asuransi untuk menutup pinjaman yang gagal bayar. CoC tersebut dapat menjaga kredibilitas anggota asosiasi sekaligus menjaga koordinasi pelaku yang tergabung dalam AFTECH. Asosiasi berupaya menjaga ekosistem yang kolaboratif yang dapat menguntungkan para pelaku industri dan perekonomian secara nasional.

Untuk mengoptimalkan pengawasan, OJK juga telah memulai untuk menjembatani dengan otoritas lain, seperti Kementerian Komunikasi dan Informatika dalam hal sistem elektronik untuk keperluan fintech. Hanya demikian, proses seperti ini akan lebih baik jika terdapat lembaga yang tersentral di dalam OJK untuk menangani persoalan fintech termasuk isu koordinasi.

Pelaksanaan pengawasan terhadap fintech termasuk P2P Lending tidak terlepas dari peran AFTECH. AFTECH menjembatani pelaku usaha dengan regulator untuk memberikan rekomendasi best practice dalam rangka pembuatan regulasi yang mampu menyokong pertumbuhan industri.

AFTECH juga memiliki satuan tugas berbagai sektor fintech seperti payment, Lending, capital market, insurtech, cybersecurity, dan financial inclusion working group yang mengadakan dikusi regular untuk menanggapi isuisu teknis fintech yang sedang berkembang. Dalam hal edukasi, AFTECH mengundang berbagai expert di bidang masing- masing dalam workshop regular untuk bertukar ide dan keahlian dengan para pelaku usaha lain. AFTECH juga menyediakan database dan riset sebagai bahan pengetahuan dari industri fintech kepada para anggota.

Pelaksanaan pengawasan juga bukan tanpa kendala. Beberapa kendala yang dihadapi saat ini, di antaranya mengenai pengaturan fintech yang membutuhkan koordinasi lintas sektor/otoritas. Pelaksanaan pengawasan terhadap berjalannya kegiatan usaha daam bidang fintech melibatkan beberapa sektor. Namun, Kondisi saat ini ialah belum adanya departemen tersentral (Departemen Fintech OJK) untuk menyelesaikan segala permasalahan fintech dari sisi OJK, Selain itu, ritme inovasi yang begitu cepat, kadangkala tidak mampu diimbangi oleh kecepatan regulator sehingga banyak penyelesaian permasalahan yang tertunda. 
Selain itu, permasalahan sertifikasi dalam bidang teknologi informasi terhadap perusahaan penyelenggara terkait dengan assessment teknologi informasi yang berkoordinasi dengan Kementerian Komunikasi dan Informatika, juga menjadi salah satu kendala karena tidak dapat berjalan beriringan. Padahal perusahaan- perusahaan fintech secara garis besar berdiri pada bidang teknologi informasi.

Dari sisi fintech yang berdasarkan prinsip syariah, yang mana hukum Islam, lebih khusus hukum ekonomi syariah dalam memberikan pandangan hukum mengenai persoalan fintech. Layanan berbasis teknologi finansial (fintech) Menurut konteks fikihnya, hal ini masuk kategori fathu al-dzari'ah ${ }^{18}$ yang intinya adalah terobosan peluang melakukan inovasi baru.

Fintech sejatinya adalah menggunakan kecanggihan teknologi untuk sebuah proses transaksi keuangan yang telah ada sebelumnya, berpindah dalam ranah digital, maka tentu masalahnya akan semakin komplek, karena sudah barang tentu wujud jaminan keamanan akan menjadi sangat diprioritaskan. fintech sifatnya adalah menyederhanakan alur, yang semula harus bertatap muka dalam melakukan akad dengan wujud jaminan yang bisa diketahui secara fisik, berubah menjadi hanya berbasis link atau jaringan. ${ }^{19}$

Pandangan ekonomi syariah, khususnya ranah fiqh muamalah yang hakekatnya sebuat traksaksi, adalah akad yang terjadi antara satu pihak dengan lainnya, dalam konteks fiqh muamalah disebut ijab qabul. Akibat dari ketiadaan pertemuan langsung transaksi yang terjadi antara dua pihak yang berakad, masalah yang timbul dalam ranah figh, akibat hadirnya fintech ini adalah seputar permasalahan ittihadu al-majlis al-'aqdi (konsep kesatuan majelis transaksi). Imam Nawawi ${ }^{20}$ dalam kitab Raudlatu al-Thalibin sekilas menyampaikan:

"Yang dimaksud dengan majelis yang disyaratkan melakukan penyerahan di dalamnya adalah majelis tawajub (majelis saling menerima antara dua

${ }^{18}$ Elkafilah," fathu al-dzari'ah" : https://elkafilah.wordpress.com/2012/05/16/fathu-aldzariah/. Diakses juni 2020.

${ }^{19}$ Muhammad Syamsudin, “ Fintech dalam pandangan hukum Islam: https://bincangsyariah.com/kalam/fintech-dalam-pandangan-hukum-islam/. Diakses pada Juli 2020

${ }^{20} \mathrm{Al}$-Imam al-Allamah Abu Zakaria Muhyuddin bin Syaraf an-Nawawi ad-Dimasyqi atau lebih dikenal sebagai Imam Nawawi, https://id.wikipedia.org/wiki/Abu_Zakaria_Muhyuddin_anNawawi. 
atau lebih pelaku transaksi), yaitu suatu gambaran yang bisa memberikan kesan telah terjalinnya relasi ijab dan qabul, baik dengan melihat tempat berlangsungnya akad ataupun tidak." 21

Dalam ranah fikih, jika suatu shighah akad harus disampaikan secara tertulis, maka itu artinya akad berlangsung secara hukmiy. Apabila penerimaan secara hukmiy belum cukup maka lebih jauh, Syeikh Wahbah al-Zuhaili menjelaskan:

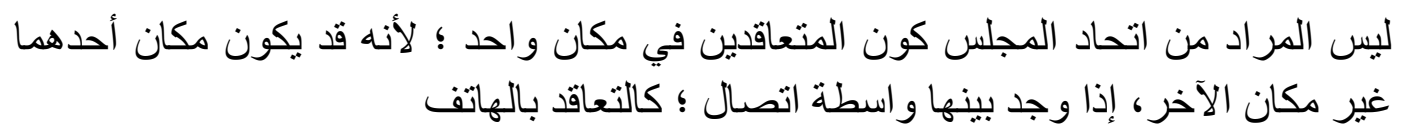

Artinya: "Bukanlah yang dimaksud sebagai tunggal majelis akad itu kondisi dua orang yang berakad sebagai harus ada di satu tempat. Terkadang posisi salah satu dari kedua pihak ini tidak berada di lokasi yang sama dengan pihak lainnya, namun ada wasilah yang bisa menghubungkan antara keduanya sehingga terjalin komunikasi, misalnya bertransaksi lewat pesawat telepon." 22

Apabila konsep ittihad al-majelis tidak mensyaratkan harus hadirnya kedua pihak di dalam majelis akad yang sama, tetapi bisa melalui wasilah teknologi informasi, maka itu artinya penerimaan secara hukmiy (lewat tulisan/ pesan digital) itu berarti dibenarkan oleh syariat. Dengan demikian, pembukaan akun / rekening digital sebagai wasilah transaksi lewat media, adalah dibenarkan juga oleh syariat.

Adapun peluang penyalahgunaan penerbit fintech dalam mengelola dana konsumennya bisa diantisipasi. Syariat menggariskan bahwa bila terjadi sebuah akad yang berbasis hukmiy (turunan), maka perlu adanya keberadaan penjamin. Tentu saja, penjaminnya ini membutuhkan pihak ketiga sebagai wasilah. Dan pihak ketiga ini adalah pemerintah. Rupanya, Bank Indonesia sudah mengantisipasi kemungkinan penyalahgunaan fintech ini dengan menerbitkan PBI Nomor 19/12/PBI/2017 tentang Penyelenggaraan Teknologi Finansial.

Sebelum diselenggarakan pun, BI memberlakukan kewajiban uji coba terbatas melalui Peraturan Dewan Anggota Gubernur (PADG) Nomor 19/14/PADG/2017 tentang Ruang Uji Coba Terbatas (Regulatory Sandbox) Teknologi Finansial. Berbekal peraturan ini, maka lengkap sudah wujud regulasi

${ }^{21}$ Imam Nawawi dalam kitab : "Raudlatu al-Thalibin”,Juz 5, h. 687.

22 Wahbah al-zulaihi, dalam kitab “Al-Fiqhu al-Islami wa Adillatuhu”, Juz 4, hlm.106. 
tentang penjaminan itu. Dengan demikian, tidak diragukan lagi bahwa fintech bisa berlaku dan dibenarkan secara syara' selagi tidak ada illat-illat keharaman yang terjadi di dalamnya, seperti riba, spekulatif (maisir), gharar (penipuan), dan kecurangan (ghabn) serta dlarar (bersifat merugikan).

\section{Penutup}

Upaya perlindungan hukum terhadap perkembangan fintech yang semakin pesat mendorong kemajuan ekonomi nasional pemerintah membuat regulasi kebijakan yang mengatur serta mengawasi fintech tersebut. Dalam implemetasi perwujudan supremasi hukum yang berkeadilan menindak para pelanggar fintech lebih tegas dan memberikan efek jera, untuk mengawal itu semua, diperlukan sinergitas dan berbagai upaya agar inklusi layanan keuangan semakin maju.

Dalam konteks syariah pun memiliki rujukan jelas serta aspek hukum yang jelas sesuai dengan pandangan hukum Islam dan hukum positif. Kendati demikian, upaya mengatasi persoalan pelanggaran fintech, agar ke depan lebih diatur dalam peraturan atau undang-undang khusus mengenai fintech. Dorongan penegakan hukum yang lebih efisien diperlukan adanya suatu undang-undang khusus mengenai fintech mulai dari ketentuan penyeleggaran fintech yang baik dan benar sampai kepada aturan tindakan hukum ketika terjadi pelanggaran fintech, aspek hukum dalam legalisasi hukum nasional financial teknologi akan menjadi konsep kajian penelitian penulis di masa mendatang.

\section{DAFTAR PUSTAKA}

Bagir Manan, "Hukum positif Indonesia : Suatu kajian teoritik", FH UII Press, Yogyakarta ,2004.

Imam Nawawi kitab : “Raudlatu al-Thalibin”. Pustaka Azzam. Indonesia.

Wahbah al-zulaihi, kitab "Al-Fiqhu al-Islami wa Adillatuhu”. Darul Fikr, Beirut. tth.

Budi Wibowo,"Analisa Regulasi Fintech Dalam Membangun Perekonomian di Indonesia", dalam https://www.academia.edu/35563302/analisa_regulasi _fintech_dalam_membangun_perekonomian_di_indonesia.

Greg Buchak, "et al”, "Fintech, Regulatory Arbitrage, And The Rise Of Shadow Banks", National Bureau of Economic Research, No.23288, Sepetember 2018

Ernama Santi, "et al”, 'Pengawasan Otoritas Jasa Keuangan Terhadap Financial Technology (Peraturan Otoritas Jasa Keuangan Nomor 77/Pojk.01/2016)", Diponegoro Law Journal, Vol.6 No.3, Juli 2017.

Hida Hiyanti, "et al", "Peluang dan Tantangan Fintech (Financial Technology) Syariah di Indonesia", Jurnal Ilmiah Ekonomi Islam (JIEI), Vol.5 No.3, 2019. 
Egi Alvian Firmansyah, "et al", "Islamic Financial Technology (Fintech): Its Challenges And Prospect", Proceedings of the Achieving and Sustaining SDGs 2018 Conference: Harnessing the Power of Frontier Technology to Achieve the Sustainable Development Goals (ASSDG 2018) Atlantis Press, January 2019.

Mireza Fitriadi "et al", "Kedudukan Otoritas Jasa Keuangan Terhadap Perusahaan Modal Ventura Asing dalam Melakukan Pembiayaan Secara Langsung di Indonesia", Jurnal Penelitian Hukum, Vol. 1, Nomor 2, Juli 2014.

Peraturan Bank Indonesia Nomor 19/12/PBI/2017 Tentang Penyelenggaraan Teknologi Finansial.

Peraturan Otoritas Jasa Keuangan Nomor 77/POJK.01/2016 Tentang Layanan Pinjam Meminjam Uang Berbasis Teknologi Informasi.

Fatwa Dewan Syariah Nasional-Majelis Ulama Indonesia No:117/DSNMUI/II/2018 Tentang Layanan Pembiayaan Berbasis Teknologi Informasi Berdasarkan Prinsip Syariah.

Peraturan Anggota Dewan Gubernur BI Nomor 19/14/PADG/2017 tentang Ruang Uji Coba Terbatas (Regulatory Sandbox) Teknologi Finansial.

Muhammad Mufid, 2016. Wawancara "Pelaksanaan Pengawasan OJK terhadap Financial Technology" di OJK. Jakarta, 12 April 2016.

M. Ajisatria Suleiman, 2016. Wawancara "Pelaksanaan Pengawasan OJK terhadap Financial Technology" di Asosiasi Financial Technology Indonesia. Jakarta, 11 April 2017.

Roy Franedya, Tito Bosnia ; “ ini dia empat jenis fintech di Indonesia"; https://www.cnbcindonesia.com/tech/20180110145800-37-1126/ini-diaempat-jenis-fintech-di-indonesia., diakses pada 14 juli 2020.

https://www.bi.go.id/id/sistem-pembayaran/fintech/Content : diakses pada 1 agustus 2020.

https://id.m.wikipedia.org/wiki/Inklusi_keuangan.

Jimmy Ramadhan Azhari : “ Terjerat utang online, supir taksi tulis surat sebelum gantung diri”;https://megapolitan.kompas.com/read/2019/02/11/14544 111/terjerat-utang-online-sopir-taksi-tulis-surat-sebelum-gantung-diri. diakses pada 10 juli 2020.

Agustinus Respati ; " Banyak Kasus, Tingkat Kepercayaan Terhadap Fintech Menciut"; https://www.google.com/amp/amp.kontan.co.id/news/banyakkasus-tingkat-kepercayaan-terhadap-fintech-menciut, diakses pada 14 agustus 2020 . 